\title{
Daya Hambat Ekstrak Spons Laut Callyspongia sp terhadap Pertubuhan Bakteri Staphylococcus aureus
}

\author{
${ }^{1}$ Yanti. Y. Warbung, ${ }^{2}$ Vonny N. S. Wowor, ${ }^{3}$ Jimmy Posangi \\ ${ }^{1}$ Mahasiswa Program Studi Kedokteran Gigi Fakultas Kedokteran Universitas Sam Ratulangi \\ ${ }^{2}$ Dosen di Program Studi Kedokteran Gigi Fakultas Kedokteran Universitas Sam Ratulangi \\ ${ }^{3}$ Dosen di Bagian Farmakologi dan Terapi Fakultas Kedokteran Universitas Sam Ratulangi \\ Email: gekikawa_y2w@yahoo.com
}

\begin{abstract}
ABSTRAK
Staphylococcus aureus merupakan salah satu mikroflora normal di rongga mulut, tetapi bisa bersifat patogen jika dipengaruhi faktor predisposisi seperti perubahan kuantitas bakteri dan penurunan daya tahan tubuh host. Beberapa penyakit dalam rongga mulut yang dapat disebabkan oleh bakteri ini yaitu abses, gingivitis, angular cheilitis, parotitis, staphylococcal mucositis dan denture stomatitis. Saat ini angka resistensi bakteri Staphylococcus aureus terhadap beberapa jenis antibiotik sudah cukup tinggi. Oleh karena itu, perlu dicari bahan alternatif yang dapat mengatasi bakteri ini. Spons laut merupakan hewan metazoa yang tergolong Filum porifera yang banyak terdapat di Indonesia dan dapat dijadikan bahan alternatif, karena mengandung senyawa steroid, alkaloid, flavonoid dan triterpenoid. Penelitian ini dibuat untuk mengetahui daya hambat ekstrak spons laut Callyspongia sp. dalam menghambat pertumbuhan bakteri Staphylococcus aureus. Ekstraksi spons laut Callyspongia sp. menggunakan metode maserasi dengan pelarut etanol 96\%. Penelitian ini menggunakan metode modifikasi KirbyBauer. Hasil penelitian menunjukkan bahwa diameter zona hambat ekstrak yang dievaporasi dengan vacuum rotary evaporator mencapai $18,1 \mathrm{~mm}$. Diameter zona hambat ekstrak yang dievaporasi dengan oven mencapai $13,7 \mathrm{~mm}$ dan masih terlihat jelas dalam masa pengamatan 2 × 24 jam. Dari penelitian ini disimpulkan bahwa ekstrak spons laut Callyspongia sp. dapat menghambat pertumbuhan bakteri Staphylococcus aureus yang terdapat dalam rongga mulut.
\end{abstract}

Kata kunci : spons laut Callyspongia sp., daya hambat, Staphylococcus aureus.

\begin{abstract}
Staphylococcus aureus is one of the normal flora in oral cavity, but these bacteria can be pathogen if there are predisposing factors such as changes in quantities of bacteria and decreasing host resistance. Some oral diseases that caused by Staphylococcus aureus are abscess, gingivitis, angular cheilitis, parotitis, staphylococcal mucositis and denture stomatitis. Nowadays, the resistance rates of Staphylococcus aureus have increased. Therefore, exploration the alternative materials that can inhibite the growth of bacteria is needed. Marine sponges are metazoan animals that classified in the Phylum Porifera that found in Indonesia and can be used as the alternative materials, because it contains steroids, alkaloid, flavonoid and anthraquinone. The purpose of this study is to determine the inhibition of marine sponges Callyspongia sp. extract in inhibiting the growth of Staphylococcus aureus. The extraction method was maceration with ethanol $96 \%$ as the solvent. This study was used modification of Kirby-Bauer method. The result showed that the clear zone diameter of extract that evaporated with vacuum rotary evaporator is $18,1 \mathrm{~mm}$. The clear zone diameter of extract that evaporated with oven is 13,7 mm and the clear zone can last up to $2 \times 24$ hours. This study concluded that the extract of marine sponges Callyspongia sp. can inhibit the groth of Staphylococcus aureus in oral cavity.
\end{abstract}

Keywords: marine sponges Callyspongia sp., the inhibition, Staphylococcus aureus. 


\section{PENDAHULUAN}

Mulut kaya akan mikroorganisme, di antaranya yaitu Staphylococcus epidermidis, Staphylococcus aureus, dan beberapa mikrokokus berpigmen yang tergolong mikroflora normal. Mikroflora normal ialah organisme yang umum ditemukan secara alamiah pada orang sehat dan hidup dalam hubungan yang seimbang dengan host, dapat bersifat menetap atau tidak menetap. Mikroflora yang menetap tersebut dapat dikatakan tidak menyebabkan penyakit dan mungkin menguntungkan bila berada di lokasi yang semestinya dan tanpa adanya keadaan abnormal. Sebaliknya bila ada faktor predisposisi seperti perubahan kuantitas mikroorganisme menjadi tidak seimbang dan penurunan daya tahan tubuh host, maka mikroflora normal dapat menyebabkan penyakit. ${ }^{1}$

Staphylococcus aureus sebagai salah satu mikroflora normal yang berada di dalam mulut, bilamana dipengaruhi oleh faktor predisposisi seperti di atas dapat menimbulkan infeksi. Beberapa penyakit dalam rongga mulut dan sekitarnya yang dapat disebabkan oleh Staphylococcus aureus yaitu abses, gingivitis, angular cheilitis, parotitis, staphylococcal mucositis dan denture stomatitis. ${ }^{1-4}$

Pemberian antibiotik dalam dosis dan jenis yang tepat diperlukan untuk menangani berbagai kasus infeksi yang terjadi. Antibiotik ialah bahan organik yang dihasilkan oleh mikroorganisme, memiliki kapasitas untuk menghancurkan, menekan multiplikasi, atau mencegah aktivitas organisme. Antibiotik yang paling sering digunakan oleh dokter gigi dalam mengatasi infeksi pada rongga mulut yaitu Amoksisilin. Hal tersebut diperkuat dengan suatu penelitian di Yogyakarta yang dilakukan oleh Andari pada tahun 2002 yang menyatakan bahwa Amoksisilin merupakan obat generik yang paling banyak digunakan di apotik wilayah Yogyakarta. ${ }^{1,5,6}$

Pemakaian atau peresepan antibiotik yang tidak tepat (irrational prescribing) dapat menimbulkan resistensi kuman. Resistensi kuman terhadap antibiotik mengakibatkan penyakit sulit diobati karena kuman menjadi kebal, sehingga harus menggunakan antibiotik dengan dosis lebih tinggi, sebagai konsekuensinya harga menjadi lebih tinggi. ${ }^{7}$

Tingkat resistensi Staphylococcus aureus terhadap antibiotik yang paling sering digunakan sudah mencapai angka persentase yang tinggi. Oleh karena itu, dengan mengingat bahwa sifat patologis bakteri ini sangat besar pengaruhnya di dalam rongga mulut, maka penemuan bahan alternatif yang dapat mengatasi bakteri ini merupakan suatu kebutuhan yang mendesak. ${ }^{5}$

Seiring perkembangan teknologi yang semakin canggih sangat memungkinkan pengembangan obat dari bahan alam. Penggunaan obat dari bahan alam secara umum dinilai lebih aman dan memiliki efek samping yang relatif lebih kecil daripada penggunaan obat modern. Keuntungan lainnya yaitu harganya relatif murah serta bahannya lebih mudah didapat dibandingkan dengan obat modern yang harganya lebih mahal dan kebanyakan harus dipasok dari luar negeri. ${ }^{8}$

Indonesia merupakan salah satu negara dengan keanekaragaman hayati laut tertinggi di dunia. Berdasarkan penelitian yang dilakukan oleh Hartono pada tahun 2009, diperkirakan ada lebih dari 35.000 spesies biota laut memiliki potensi sebagai bahan obat-obatan, sementara yang dimanfaatkan baru sekitar 5000 spesies. Untuk itu, pengembangan kekayaan bahari sebagai bahan obat-obatan masih sangat dibutuhkan dan dapat membantu dalam upaya peningkatan kesehatan masyarakat. ${ }^{9}$

Spons merupakan salah satu kelompok biota laut yang terdapat di perairan Indonesia dengan jumlah 850 jenis dan berpotensi untuk menghasilkan metabolit sekunder yang memiliki sifat bioaktif. Spons ialah hewan berpori yang bersifat filter feeder sehingga menjadi habitat bagi mikroorganisme untuk tinggal dalam 
tubuhnya. Menurut penelitian Muniarsih pada tahun 1999, hewan laut ini mengandung senyawa aktif yang persentase keaktifannya lebih besar dibandingkan dengan senyawa-senyawa yang dihasilkan oleh tumbuhan darat. Pada tahun 1980, ditemukan salah satu metabolit dari spons laut Luffariella variabilis yang terdapat di Palauan dengan aktivitas sebagai antibiotik terhadap Pyogenes streptomyces dan Staphylococcus aureus ${ }^{10-13}$

Pembentukan metabolit sekunder dipengaruhi oleh lingkungan, sehingga diasumsikan bahwa pada lingkungan yang berbeda walaupun jenisnya sama akan memberikan fungsi yang berbeda, apalagi kalau sudah berbeda jenisnya. Oleh karena itu, dalam penelitian ini penulis akan mengambil spons Callyspongia sp. yang terdapat di perairan Pantai Malalayang Sulawesi Utara. Callyspongia sp. merupakan spons yang ditemukan di hampir seluruh perairan di Indonesia sehingga mudah diperoleh.

Proses penguapan atau evaporasi dapat memengaruhi kemampuan senyawa aktif spons dalam menghambat pertumbuhan bakteri. Oleh karena itu, penulis menggunakan dua metode evaporasi yakni evaporasi hampa udara menggunakan vacuum rotary evaporator serta evaporasi dengan udara dan panas menggunakan oven. Hal tersebut dimaksudkan untuk melihat apakah ada perbedaan signifikan antara kedua metode tersebut terhadap kemampuan ekstrak dalam menghambat pertumbuhan bakteri.

Dalam penelitian ini, penulis akan menguji apakah ekstrak spons laut Callyspongia sp. dapat menghambat pertumbuhan bakteri Staphylococcus aureus dan bagaimana daya hambatnya. ${ }^{10,14}$

\section{METODE PENELITIAN}

\section{Alat dan Bahan}

Penelitian ini merupakan penelitian eksperimental laboratoris dengan menggunakan post test only control group design. Bahan yang digunakan dalam penelitian ini yaitu sampel spons laut Callyspongia sp. yang diambil dari perairan pantai Malalayang Manado. Biakan bakteri Staphylococcus aureus diambil dari Laboratorium Mikrobiologi Fakultas Kedokteran Universitas Hasanuddin Makassar. Adapun bahan lainnya yang digunakan dalam penelitian ini yaitu nutrien agar (NA), agar MüllerHinton (MHA), brain heart infusion broth (BHI-B), etanol 96\%, amoksisilin, larutan $\mathrm{BaCl}_{2} 1 \%$, larutan $\mathrm{H}_{2} \mathrm{SO}_{4} 1 \%$ dan akuades.

Alat-alat yang digunakan yaitu cawan petri, tabung reaksi, pinset, kapas lidi steril, oven, inkubator, api bunsen, jarum ose, jangka sorong, sendok plastik, timbangan, tabung erlenmeyer, kompor, kamera, spidol, autoclave, vacuum rotary evaporator, masker dan sarung tangan.

\section{Metode Penelitian}

a. Sterilisasi alat

Alat-alat yang digunakan dalam penelitian ini disterilkan terlebih dahulu. Alat-alat gelas disterilkan dalam oven pada suhu $170^{\circ} \mathrm{C}$ selama \pm 1 jam (sterilisasi kering). Media disterilkan dalam autoclave pada suhu $121^{\circ} \mathrm{C}$ selama 15 menit (sterilisasi basah)

b. Ekstraksi spons laut Callyspongia sp.

Sampel spons ditimbang, dipotongpotong kemudian dimaserasi dengan etanol 96\% selama 24 jam dengan perbandingan 1:2 (w/v). Setelah itu, sampel disaring sehingga diperoleh debris I dan filtrat I. Filtrat I dikumpulkan dalam wadah, sedangkan debris I dimaserasi lagi dengan etanol 96\% selama 24 jam lalu disaring, sehingga memperoleh debris II dan filtrat II. Debris II diberikan perlakuan yang sama dengan sebelumnya hingga diperoleh debris III dan filtrat III. Filtrat III yang diperoleh digabungkan dengan filtrat I dan II, lalu disaring. Sebagian filtrat yang telah disaring diuapkan dengan rotary vacuum 
evaporator pada temperatur $40^{\circ} \mathrm{C}$ sampai etanol menguap. Filtrat lainnya dievaporasi di dalam oven. Bagian sisa dari penguapan etanol disebut ekstrak pekat. Ekstrak pekat disimpan dalam referigerator dengan suhu $4^{0} \mathrm{C}$.

\section{c. Prosedur pengambilan bakteri}

Bakteri Staphylococcus aureus yang digunakan dalam penelitian ini merupakan stok bakteri murni yang diisolasi dari pus dalam rongga mulut, berasal dari Laboratorium Mikrobiologi Fakultas Kedokteran Universitas Hasanuddin Makassar. Bakteri ini disimpan pada agar miring kemudian dimasukkan ke dalam wadah steril yang berada dalam suasana anaerob dan ditutup sehingga sterilisasi tetap terjaga, untuk dibawa ke daerah tempat penelitian. Bakteri yang sudah tersedia dalam botol wadah steril dikirim melalui jasa penitipan kilat ke Manado. Setelah tiba di Manado, bakteri dimasukkan ke referigerator dengan suhu $-20^{\circ} \mathrm{C}$. Jika sudah mendekati waktu untuk digunakan, bakteri diinkubasi dalam inkubator pada suhu $37^{\circ} \mathrm{C}$.

d. Pembuatan media peremajaan bakteri

Nutrien agar (NA) sebanyak 23 gram dilarutkan dengan 1 liter akuades menggunakan tabung erlenmeyer, kemudian dihomogenkan dan dituang ke dalam tabung reaksi steril yang ditutup dengan aluminium foil. Media tersebut disterilkan di dalam autoclave pada suhu $121{ }^{\circ} \mathrm{C}$ selama 15 menit. Media yang telah steril dibiarkan pada suhu ruangan selama 30 menit sampai media memadat pada kemiringan $30^{\circ}$.

e. Pembuatan suspensi bakteri

Media brain heart infusion broth (BHI-B) ditimbang sebanyak 37 gram dan dilarutkan dalam 1 liter akuades dalam tabung erlenmeyer. Media disterilisasi dalam autoclave pada suhu $121^{\circ} \mathrm{C}$ selama 15 menit, selanjutnya dituang dalam tabung reaksi sebanyak $7 \mathrm{ml}$.

f. Pembuatan lapisan pembenihan

Agar Müller-Hinton (MHA) ditimbang sebanyak 38 gram menggunakan 1 liter akuades sebagai pelarut. Media disterilisasi dalam autoclave pada suhu $121^{\circ} \mathrm{C}$ selama 15 menit, selanjutnya dimasukkan dalam cawan petri sebanyak $10 \mathrm{ml}$ dan dibiarkan hingga mengeras. Pada lapisan berikutnya dituang media yang sama sebanyak $20 \mathrm{ml}$. Pencadang sebanyak 3 buah dengan diameter 6 $\mathrm{mm}$ yang telah disterilisasi sebelumnya, diletakkan tegak lurus dengan jarak yang seragam satu sama lain. Pencadang diangkat dengan menggunakan pinset setelah media mengeras, sehingga terbentuk 3 buah sumur. Perlakuan di atas dibuat pada 3 cawan petri.

g. Pembuatan standar kekeruhan larutan McFarland

Larutan baku McFarland terdiri atas dua komponen, yaitu larutan $\mathrm{BaCl}_{2} 1 \%$ dan $\mathrm{H}_{2} \mathrm{SO}_{4} 1 \%$. Larutan $\mathrm{BaCl}_{2} 1 \%$ sebanyak $0,05 \mathrm{ml}$ dicampur dengan larutan $\mathrm{H}_{2} \mathrm{SO}_{4} 1 \%$ sebanyak $9,95 \mathrm{ml}$ dan dikocok homogen. Nilai absorban larutan baku harus berada di kisaran 0,08 sampai dengan 0,13. Larutan baku McFarland 0,5 ekuivalen dengan suspensi sel bakteri dengan konsentrasi $1,5 \times 10^{8} \mathrm{CFU} / \mathrm{ml}$.

h. Peremajaan bakteri dan penanaman pada lapisan pembenihan

Bakteri Staphylococcus aureus yang disimpan di media agar yang diambil dari Makassar, diambil dengan jarum ose steril, lalu ditanamkan pada media agar miring dengan cara menggores. Bakteri yang telah digores pada media agar diinkubasi dalam inkubator pada suhu $37^{0} \mathrm{C}$ selama $1 \times 24$ jam.

Bakteri yang telah diinkubasi diambil koloninya dari media agar miring dengan menggunakan jarum 
ose steril. Koloni yang diambil dimasukkan ke dalam media BHI-B sampai kekeruhannya sama dengan standar McFarland. Lidi kapas steril dicelupkan ke dalam suspensi bakteri hingga basah. Lidi kapas diperas dengan menekankan pada dinding tabung reaksi bagian dalam, kemudian digores merata pada media MHA.

i. Pembuatan larutan kontrol positif

Kontrol positif dibuat dengan sediaan bubuk obat amoksisilin. Pembuatan larutan ini mengacu pada minimal inhibitory concentration (MIC) amoksisilin terhadap Staphylococcus aureus, yakni 2,0178 $\mathrm{mg} / \mathrm{ml}$ yang dicampur dengan pelarut akuades hingga homogen.

\section{Metode Pengujian}

Metode pengujian yang digunakan ialah metode modifikasi Kirby-Bauer dengan menggunakan sumuran. Sumur pertama yang sudah terbentuk pada media agar di 3 cawan petri diisi dengan larutan ekstrak pekat spons laut Callyspongia sp. yang sudah dilarutkan dengan etanol $96 \%$ dan dievaporasi dengan vacuum rotary evaporator. Sumur kedua diisi dengan ekstrak pekat spons laut yang sudah dilarutkan dengan etanol $96 \%$ dan dievaporasi dengan oven. Sumur ketiga diisi dengan kontrol positif yaitu amoksisilin yang sudah dilarutkan dengan akuades, dan pada sumur yang keempat yang merupakan kontrol negatif diisi dengan etanol 96\%. Setelah itu, cawan petri diinkubasi dalam inkubator pada suhu $37^{0} \mathrm{C}$ selama 24 jam.

\section{Pengamatan dan Pengukuran}

Pengamatan dilakukan setelah 24 jam dan 48 jam masa inkubasi. Zona bening merupakan petunjuk kepekaan bakteri terhadap bahan antibakteri yang digunakan sebagai bahan uji dan dinyatakan dengan luas zona hambat. Zona hambat yang terbentuk di sekitar sumur diukur diameter vertikal dan diameter horizontal dengan satuan milimeter $(\mathrm{mm})$ menggunakan jangka sorong. Pengukuran diameter zona hambat dapat dilihat pada Gambar 1.

$\mathrm{D}_{2}$

$\mathrm{D}_{\mathrm{s}}$

$\mathrm{D}_{\mathrm{s}}$

Gambar 1. Pengukuran diameter daya hambat

Keterangan:
: Zona hambat
$\mathrm{D}_{1} \quad$ : Diameter vertikal
$\mathrm{D}_{2} \quad$ : Diameter horizontal
Ds : Diameter sumur

Diameter zona hambat diukur dengan rumus :

$$
\frac{\left(D_{1}-D_{S}\right)+\left(D_{2}-D_{S}\right)}{2}
$$

5. Analisis Data
Data hasil penelitian dihitung secara manual, kemudian diolah secara komputerisasi menggunakan Microsoft Excel. Data yang sudah diolah, disajikan dalam bentuk gambar, tabel dan tulisan. 


\section{HASIL DAN PEMBAHASAN}

1. Hasil

Pengujian daya hambat dilakukan dengan mengukur diameter zona hambat yang dihasilkan pada media yang mengandung bakteri Staphylococcus aureus setelah dilakukan inkubasi selama 24 jam pada suhu $37^{\circ} \mathrm{C}$. Media yang sudah diinkubasi dan siap diamati dapat dilihat pada Gambar 2.

A

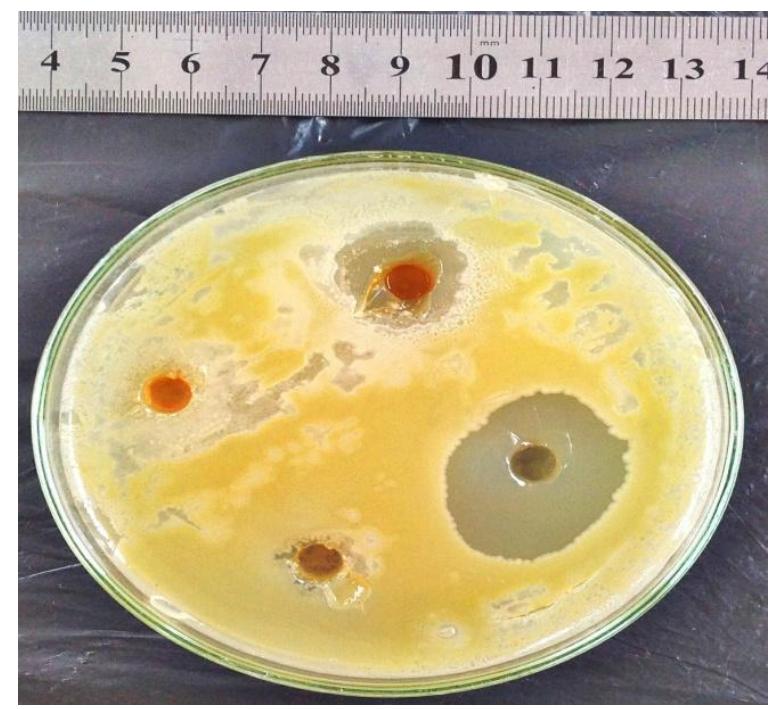

C

D

B

Gambar 2. Sumur pada media Agar Müller-Hinton

Keterangan :

A : Sumur yang diberi ekstrak spons laut Callyspongia sp. yang dievaporasi dengan vacuum rotary evaporator.

B : Sumur yang diberi ekstrak spons laut Callyspongia sp. yang dievaporasi dengan oven.

C : Sumur yang diberi etanol $96 \%$.

D : Sumur yang diberi amoksisilin yang dilarutkan dengan akuades.

Pengamatan dilakukan dengan mengukur diameter zona hambat yang terbentuk di sekitar sumur menggunakan jangka sorong dengan satuan milimeter (mm). Pengukuran diameter yang dilakukan dengan menggunakan jangka sorong. Zona hambat yang dihasilkan dari masing-masing perlakuan memiliki diameter yang berbeda-beda dan bentuk yang tidak beraturan. Oleh karena itu, pengamatan dilakukan dengan cara mengukur diameter horizontal dan diameter vertikal dari zona hambat yang terbentuk di sekitar sumur. Kedua diameter tersebut dimasukkan ke dalam rumus untuk mencari nilai rerata diameter zona hambat. Hasil pengukuran diameter zona hambat yang terbentuk di sekitar sumur dapat dilihat pada Tabel 1. 
Tabel 1. Diameter zona hambat di sekitar sumur pada pengamatan 1 x 24 jam

Diameter zona hambat (mm)

\begin{tabular}{ccccc} 
PENGULANGAN & Ekstrak I & Ekstrak II & $\begin{array}{c}\text { Kontrol } \\
\text { positif }\end{array}$ & $\begin{array}{c}\text { Kontrol } \\
\text { negatif }\end{array}$ \\
$\mathbf{1}$ & 19,1 & 12,6 & 19,5 & - \\
$\mathbf{2}$ & 13,4 & 15,1 & 16,6 & - \\
$\mathbf{3}$ & 22 & 14,3 & 20,1 & - \\
Rerata & 18,1 & 13,7 & 18,7 & - \\
\hline
\end{tabular}

Keterangan:

Ekstrak I : Ekstrak yang dievaporasi dengan vacuum rotary evaporator.

Ekstrak II : Ekstrak yang dievaporasi dengan oven

Kontrol positif : Amoksisilin yang dilarutkan dengan akuades

Kontrol negatif : Etanol 96\%

Data pada Tabel 1 menunjukkan nilai diameter zona hambat yang dihasilkan di sekitar sumur dengan berbagai perlakuan. Dari nilai tersebut tampak bahwa terdapat zona hambat yang terbentuk di sekitar sumur yang diberi ekstrak spons laut Callyspongia sp. di setiap pengulangan.

Nilai rerata diameter zona hambat ekstrak spons laut Callyspongia sp. yang dievaporasi menggunakan vacuum rotary evaporator mencapai 18,1 mm. Ekstrak spons laut yang dievaporasi dengan oven, nilai rerata diameter zona hambatnya yaitu $13,7 \mathrm{~mm}$. Bila dibandingkan dengan kontrol positif yakni amoksisilin yang dilarutkan dengan akuades dalam konsentrasi yang sesuai dengan minimal inhibitory concentration yakni $2 \mathrm{mg} / \mathrm{ml}$, nilai rerata diameter zona hambat ekstrak spons laut Callyspongia sp. masih lebih kecil. Diameter zona hambat yang dihasilkan amoksisilin mencapai nilai rerata $18,7 \mathrm{~mm}$. Kontrol negatif pada penelitian ini yakni etanol 96\% tidak menunjukkan terbentuknya zona hambat di sekitar sumur pada semua pengulangan.

Setelah dilakukan pengamatan tersebut, media diinkubasi kembali selama 24 jam pada suhu $37^{\circ} \mathrm{C}$ tanpa diberi perlakuan tambahan. Hal tersebut dimaksudkan untuk melihat kemampuan ekstrak spons laut Callyspongia sp. setelah 2 x 24 jam. Setelah masa inkubasi 2 x 24 jam, zona hambat ekstrak yang dievaporasi dengan vacuum rotary evaporator tidak terlihat lagi, sehingga hanya zona hambat ekstrak yang dievaporasi dengan oven yang diukur. Perbandingan hasil pengukuran zona hambat di sekitar sumur yang diberi ekstrak Callyspongia sp. yang dievaporasi dengan oven dalam waktu $1 \mathrm{x}$ 24 jam dan $2 \times 24$ jam dapat dilihat pada Tabel 2. 
Tabel 2. Perbandingan diameter zona hambat ekstrak spons laut Callyspongia sp. yang dievaporasi dengan oven.

\begin{tabular}{ccc}
\hline PENGULANGAN & \multicolumn{2}{c}{ Diameter zona hambat $(\mathbf{m m})$} \\
\cline { 2 - 3 } $\mathbf{1}$ & $1 \times 24$ jam & $2 \times 24$ jam \\
$\mathbf{2}$ & 12,6 & 9,2 \\
$\mathbf{3}$ & 15,1 & 13,6 \\
Rerata & 14,3 & 11,3 \\
\hline
\end{tabular}

Setelah masa inkubasi diperpanjang selama 24 jam lagi, terlihat adanya penyempitan diameter zona hambat yang terbentuk di sekitar sumur ekstrak spons laut Callyspongia sp. yang dievaporasi dengan oven. Pada waktu 1 x 24 jam setelah inkubasi, rerata diameter zona hambat yang terbentuk ialah $13,7 \mathrm{~mm}$. Pada $2 \times 24$ jam setelah inkubasi, rerata diameter zona hambat yang terbentuk ialah $11,3 \mathrm{~mm}$. Hal tersebut menunjukkan bahwa pada 24 jam berikutnya telah terjadi penyempitan zona hambat sebesar $2,4 \mathrm{~mm}$.

\section{Pembahasan}

Kebanyakan bahan obat-obatan dihasilkan dari kekayaan alam yang hingga kini masih terus dieksplorasi untuk menemukan potensi bahan obat di dalamnya. Indonesia merupakan negara kepulauan yang besar di dunia yang memiliki wilayah laut sangat luas dan kekayaan sumberdaya alam hayati laut yang besar. Spons merupakan salah satu kelompok biota laut yang terdapat di perairan Indonesia dengan jumlah sekitar 850 jenis. ${ }^{10,12}$

Spons laut merupakan salah satu invertebrata laut yang memiliki kandungan senyawa bioaktif yang berlimpah meliputi antimikroba, inhibitor enzim, inhibitor pembelahan sel, antiviral, antifungi, antiinflamatori, antitumor dan sitotoksik. Sejumlah peneliti bidang produk alam dalam dan luar negeri melakukan penelitian untuk mendapatkan metabolit sekunder dari spons. Sejak tahun 1993, sejumlah peneliti asing datang ke
Indonesia dan menawarkan kerjasama penelitian dengan objek spons. Para pakar di negara maju antara lain Amerika, Jepang, Australia, dan Jerman melakukan penelitian untuk memperoleh aktivitas farmakologik spons. ${ }^{10,15,16}$

Penelitian ini menggunakan uji eksperimental untuk melihat adanya efek antibakteri dari ekstrak spons laut Callyspongia sp. dalam menghambat pertumbuhan bakteri Staphylococcus aureus. Penelitian ini dilakukan dengan cara membiakkan bakteri Staphylococcus aureus dalam media agar Müller Hinton disertai dengan pembentukan empat buah sumur dengan diameter $6 \mathrm{~mm}$. Evaporasi ekstrak dibedakan menjadi dua metode yakni menggunakan vacuum rotary evaporator dan oven untuk mencari tahu apakah ada efek yang signifikan pada kedua metode dalam menghambat pertumbuhan bakteri Staphylococcus aureus.

Berdasarkan zona hambat yang terbentuk diketahui bahwa baik metode evaporasi dengan oven maupun vacuum rotary evaporator memiliki kemampuan untuk menghambat pertumbuhan koloni bakteri Staphylococcus aureus. Menurut suatu penelitian yang dilakukan oleh Bell pada tahun 1984, suatu bahan dikatakan mempunyai aktivitas antibakteri apabila diameter hambatan yang terbentuk lebih besar atau sama dengan $6 \mathrm{~mm}$. Hal tersebut selaras dengan hasil penelitian yang menunjukkan bahwa zona hambat dari ekstrak yang dievaporasi dengan oven pada masing-masing pengulangan ialah 
12,6 $\mathrm{mm}, \quad 15,1 \mathrm{~mm}$ dan 14,3 $\mathrm{mm}$. Demikian juga zona hambat yang terbentuk dari ekstrak yang dievaporasi dengan vacuum rotary evaporator pada masing-masing pengulangan ialah 19,1 $\mathrm{mm}, 13,4 \mathrm{~mm}$ dan $22 \mathrm{~mm}$. ${ }^{17}$

Di sekitar sumur yang diberi etanol 96\% sebagai kontrol negatif tidak ditemukan terbentuknya zona hambat. Pemilihan pelarut menggunakan etanol 96\% dengan pertimbangan bahwa etanol mudah diperoleh, bereaksi netral, selektif dan tidak memengaruhi zat yang berkhasiat. Hal tersebut menguatkan fakta bahwa terbentuknya zona hambat di sekitar sumur yang diberi ekstrak spons laut Callyspongia sp. tidak ada pengaruh dari pelarut etanol $96 \% .^{18}$

Bila dibandingkan dengan zona hambat yang terbentuk di sekitar sumur yang diberi amoksisilin, zona hambat ekstrak spons laut Callyspongia sp. lebih kecil. Dalam penelitian ini tampak bahwa amoksisilin masih lebih efisien dalam menghambat pertumbuhan bakteri Staphylococcus aureus. Faktor yang memengaruhi terjadinya hal tersebut yakni minimal inhibitory concentration (MIC) amoksisilin telah diketahui sedangkan untuk kemampuan spons belum diketahui konsentrasi paling tepat untuk menghambat pertumbuhan bakteri Staphylococcus aureus.

Lebarnya diameter zona hambat dapat dijadikan sebagai parameter untuk melihat kekuatan senyawa bioaktif yang terkandung dalam ekstrak spons. Semakin lebar diameter zona hambat yang terbentuk mengindikasikan semakin kuatnya senyawa bioaktif itu menghambat pertumbuhan bakteri. Ekstrak yang menunjukkan zona hambat yang kecil bukan berarti sampel tersebut kurang aktif, tetapi kemungkinan tidak terdeteksi pada konsentrasi sampel uji yang digunakan atau kadar hambat umumnya belum tercapai. $^{19,16}$

Menurut Watimena pada tahun 1991, apabila daerah hambatan yang terbentuk tidak lagi bening setelah masa inkubasi 48 jam atau daerah bening ditumbuhi kembali bakteri setelah masa inkubasi 48 jam berarti zat kimia yang bersifat antibakteri yang terkandung dalam suatu bahan bersifat bakteriostatik karena hanya mampu menghambat pertumbuhan atau tidak membunuh bakteri tersebut. Hal tersebut nampak terlihat pada ekstrak spons laut Callyspongia sp. yang dievaporasi dengan vacuum rotary evaporator setelah masa inkubasi $2 \times 24$ jam, zona hambat yang terbentuk telah menjadi keruh. Hal tersebut berbeda dengan zona hambat dari ekstrak spons laut Callyspongia sp. yang dievaporasi dengan oven yang dapat bertahan hingga 2 x 24 jam masa inkubasi. Pengamatan yang dilakukan setelah $2 \times 24$ jam menunjukkan bahwa zona hambat masih terbentuk, namun diameternya telah berkurang sebanyak 2,4 mm. Oleh karena itu, kemungkinan senyawa aktif yang terkandung dalam ekstrak spons laut Callyspongia sp. pada konsentrasi yang digunakan dalam penelitian ini bersifat bakteriostatik terhadap bakteri Staphylococcus aureus. ${ }^{20}$

Senyawa aktif yang dihasilkan oleh spons diduga merupakan hasil biosintesis bakteri simbionnya. Hal tersebut terjadi karena koloni mikroba dapat mencapai $40 \%$ dari komponen penyusun tubuh spons. Simbiosis mikroba dengan spons dapat berlangsung dalam sitoplasma sel tubuh spons (simbiosis intraseluler), di sisi dalam tubuh spons (endosimbiosis ekstraseluler) dan di bagian luar tubuh spons (eksosimbiosis ekstraseluler). ${ }^{20,15}$

Hasil penelitian ini didukung oleh penelitian sebelumnya yang dilakukan oleh Haedar pada tahun 2010. Penelitiannya dilakukan dengan cara mengekstraksi bakteri Chromohalobacter sp. yang bersimbiosis dengan spons Callyspongia sp. menggunakan pelarut etil asetat dan diujikan pada bakteri Staphylococcus aureus. Penghambatan ekstrak etil asetat bakteri Chromohalobacter sp. dan ekstrak kloroform spons Callyspongia sp. menunjukkan sifat bakteriostatik terhadap 
Staphylococcus aureus. Hal tersebut menunjukkan bahwa bakteri Chromohalobacter sp. yang bersimbiosis dengan spons Callyspongia sp. mengandung senyawa antibakteri yang efektif menghambat pertumbuhan bakteri Gram positif. $^{20}$

Selain ditinjau dari bakteri yang bersimbiosis dengan spons ini, adanya aktivitas antibakteri dipengaruhi oleh kandungan ekstrak spons Callyspongia sp. Krisyuninda pada tahun 2012 melakukan isolasi senyawa bioaktif spons Callyspongia sp. dengan metode kromatografi lapis tipis (KLT) menemukan bahwa pada spons tersebut terdapat kandungan steroid, alkaloid, flavonoid dan terpenoid. Hasil penelitian tersebut didukung oleh hasil penelitian sebelumnya yang dilakukan oleh Cowan pada tahun 1999 yang menyatakan bahwa dalam ekstrak spons Callyspongia sp. terdapat senyawa steroid, alkaloid, flavonoid dan antrakuinon. $^{21,22}$

Senyawa steroid merupakan golongan senyawa triterpenoid. Senyawa ini menunjukkan aktivitas antibakteri, antifungi antitumor, neurotoksik dan antiinflamatori yang bermanfaat bagi industri farmasi. Menurut Cowan pada tahun 1999, mekanisme penghambatan bakteri oleh senyawa steroid diduga dengan cara merusak membran sel bakteri. Steroid dapat meningkatkan permeabilitas membran sel sehingga akan terjadi kebocoran sel yang diikuti dengan keluarnya materi intraseluler. ${ }^{22,23}$

Senyawa flavonoid merupakan golongan yang penting karena memiliki spektrum aktivitas antimikroba yang luas dan dapat mengurangi kekebalan pada organisme sasaran. Sifat antibakteri senyawa flavonoid ialah dengan menyebabkan terjadinya denaturasi protein di dalam sel bakteri. ${ }^{24,25}$

Suatu penelitian yang dilakukan oleh Wulandari pada tahun 2009 menunjukkan bahwa senyawa alkaloid dapat menghambat pertumbuhan bakteri. Mekanisme penghambatan bakteri oleh senyawa ini diduga dengan cara merusak komponen penyusun peptidoglikan pada sel bakteri sehingga lapisan dinding sel tidak terbentuk secara utuh dan menyebabkan kematian sel tersebut. ${ }^{24,4}$

Senyawa antrakuinon pernah diteliti oleh Rahayu pada tahun 2006, dengan melakukan ekstrak pada lidah buaya, mengemukakan bahwa senyawa ini dapat menghambat pertumbuhan bakteri patogen, seperti Eschericia coli dan Salmonella hadar. Antrakuinon mampu berperan sebagai antibiotik yang bersifat bakteriostatik. $^{26}$

Penelitian ini menunjukkan bahwa ekstrak spons laut Callyspongia sp. memiliki efek antibakteri yang menghambat pertumbuhan bakteri Staphylococcus aureus, namun kemampuannya masih kurang efisien bila dibandingkan dengan antibiotik amoksisilin.

\section{KESIMPULAN}

Berdasarkan hasil penelitian dapat disimpulkan bahwa ekstrak spons laut Callyspongia sp. dapat menghambat pertumbuhan bakteri Staphylococcus aureus. Daya hambat ekstrak spons laut Callyspongia sp. terhadap bakteri Staphylococcus aureus lebih kecil dibandingkan dengan daya hambat antibiotik amoksisilin yang merupakan kontrol positif.

\section{SARAN}

Dari penelitian ini dapat disarankan untuk melakukan penelitian lanjut mengenai daya hambat ekstrak spons laut Callyspongia sp. terhadap bakteri Staphylococcus aureus pada berbagai konsentrasi kepekatan ekstrak, sehingga dapat diketahui minimal inhibitory concentration (MIC) ekstrak terhadap bakteri Staphylococcus aureus. Penelitian ini dapat dikembangkan dengan melakukan penelitian lanjut untuk mengetahui jenis senyawa aktif spons laut Callyspongia sp. yang menghambat pertumbuhan bakteri Staphylococcus 
aureus. Selain itu, diharapkan dapat dilakukan penelitian lanjut mengenai daya hambat ekstrak spons laut Callyspongia sp. terhadap bakteri lain yang dapat menimbulkan masalah bagi kesehatan gigi dan mulut.

\section{DAFTAR PUSTAKA}

1. Syahrurachman A, Chatim A, Soebandrio A, Karuniawati A, Santoso A, Harun B, et al, editors. Buku ajar mikrobiologi kedokteran. Edisi revisi. Jakarta : Binarupa Aksara publishers. 2010;p.125-34

2. Azadeh M, Kermanshahi R, Naghavi N, Ghalayani P, Salamat F. The profil of pathogenic isolated from dental plaqueinduced gingivitis. International Journal of Molecular and Clinical Microbiology 1. 2011;p.36-9

3. Smith A, Robertson D, Tang M, Jackson M, MacKenzie D, Bagg J. Staphylococcus aureus in the oral cavity: a three-year retrospective analysis of clinical laboratory data. British dental journal. 2003;195(12): p.701-3

4. Smith AJ, Jackson MS, Bagg J. The ecology of Staphylococcus species in the oral cavity. J Med Microbiol. 2011;50(11): p.940-6

5. Haveles E. Applied pharmacology for the dental hygienist. $6^{\text {th }}$ edition. Misouri : Mosby Elsevier. 2011.

6. Andari I, Wahyono D. Penggunaan obat generik di apotek wilayah Kodya Yogyakarta pada masa krisis moneter (Maret 1997-Maret 1998). Majalah Farmasi Indonesia. 2002;13(1): p.12-20

7. Bhargavi S, Gopala V, Mukkanti K, Dinesh B, Krishna P. Increasing emergence of antibacterial resistance mainly in uropathogens: southest part of India. International journal of microbiology research. 2010;2(1): p.0106

8. Sari L. Pemanfaatan obat tradisional dengan pertimbangan manfaat dan keamanannya. Majalah Ilmu Kefarmasian. 2006;3(1): p.1-7
9. Hartono B. Kajian kesesuaian sumberdaya terumbu karang untuk pengembangan ekowisata bahari di Kelurahan Pulau Abang Kota Batam. [Online]. [cited 2013 April 17]; Available from: http://repository.ipb.ac.id/bitstream/han dle/123456789/41472

10. Rachmat R. Spons Indonesia kawasan timur. Oseanologi dan Limnologi di Indonesia. 2007;33: p.123-38

11.Ebada S, Lin W, Proksch P. Bioactive sesterterpenes and triterpenes from marine sponges: occurrence and pharmacological significance. [Online]. [updated 2010 Februari 23; cited 2013 April 17]. Available from: http://www.ncbi.nlm.nih.gov/pmc/articl es/PMC2852841/Uu

12.Suparno. Kajian bioaktif spons laut (Forifera: Demospongiae) suatu peluang altenatif pemanfaatan ekosistem karang Indonesia dalam bidang farmasi. [Makalah]. PascaSarjana IPB:2005

13.Murniasih T, Rasyid A. Potensi bakteri yang berasosiasi dengan spons asal Barrang Lompo (Makassar) sebagai sumber bahan antibakteri. Pusat Oseanografi dan LIPI:2010

14.Anonim C. Metabolit sekunder Callyspongia sp. [Online]. 2011 September 9 [cited 2013April 27]; Available from: http://www.artikelkimia.info/metabolitsekunder-callyspongia-sp-1 3021409092011

15.Handayani D, Deapati M, Marlina, Meilan. Skrining aktivitas antibakteri beberapa biota laut dari Perairan Pantai Painan, Sumatera Barat. [Makalah]. Unand : 2009

16.Rosidah, Afizia W. Potensi ekstrak daun jambu biji sebagai antibakterial untuk menanggulangi serangan bakteri Aeromonas hydrophila pada ikan gurame (Osphronemus gouramy lacepede). Jurnal akuatika. 2012;3(1):p.24 
17.De Voogd N. Indonesian sponges : Biodiversity and marine culture potential. [Tesis]. Univ of Amsterdam : 2005

18.Prishandono D, Radiati LE, Rosyidi D. Pengaruh penambahan ekstrak picung (Pangium edule) dengan air dan etanol terhadap recovery Eschericia coli dan Staphylococcus sp. serta total mikrobia pada daging sapi giling. Malang: Universitas Brawijaya.2013

19.Ismet M. Penapisan senyawa bioaktif spons Aaptos aaptos dan Petrosia sp. dari lokasi yang berbeda.[Tesis]. Pasca Sarjana IPB: 2007

20.Haedar N. Purdian H. Bioaktivitas bakteri Chromohalobacter sp. dari spons Callyspongia sp. terhadap bakteri patogen. FMIPA Universitas Hassanudin. 2010

21.Krisyuninda M. Uji toksisitas fraksi spons Callyspongia sp. dengan metode brine shrimp test dari perairan pasir putih situbondo. Institut Teknologi Sepuluh November : 2012
22.Cowan, M. Plant products as antimicrobial agents. Clin Microbio Reviews. 1999;12(4): p.564-82

23. Hardiningtyas S. Aktivitas antibakteri ekstrak karang lunak Sarcophyton sp. yang difragmentasi dan tidak difragmentasi di perairan Pulau Pramuka Kepulauan Seribu. [Skripsi]. IPB:2009

24.Wulandari R, Utami P, Hartanti D. Penapisan fitokimia dan uji aktivitas antibakteri ekstrak etanol herba pulutan (Urena lobata Linn.) Pharmacy.2009;6(1): p.5

25.Dewanti S. Antibacteri activity of bay leaf infuse (Folia syzygium polyanthum WIGHT) to Eschericia coliin-vitro. Jurnal Medika Planta. 2011;1(4)

26. Rahayu I. Aloe barbandesis Miller dan Aloe chinensis Baker sebagai antibiotik dalam pengobatan etnoveteriner unggas secara in-vitro. Jurnal protein. 2006;13(1) 